ISBN 978-93-84422-85-1

11th International Conference on Chemical, Agricultural, Biological and Environmental Sciences

(CABES-2018)

April 17-18, 2018 Kyoto (Japan)

\title{
Phytochemical Screening and Antioxidant Activity Stem Bark Extract of Xylocarpus Granatum from Nothern Buton
}

\author{
Arman Rusman ${ }^{1 *}$, Sriwulan Purnamasari ${ }^{2}$ and Haeruddin ${ }^{2}$ \\ ${ }^{1 *}$ Faculty of Pharmachy, Universitas Gadjah Mada, Yogyakarta, Indonesia \\ ${ }^{2}$ Chemistry Education of Universitas Halu Oleo Kendari, Indonesia
}

\begin{abstract}
Free radical of a species having unpaired free electrons can cause damage to the cells and trigger various diseases, It can be reduced by antioxidant compounds. This study aims to determine the content of secondary metabolites and antioxidant activity stem bark extract of Xylocarpus granatum. Stem bark of Xylocarpus granatum was macerated using etanol to obtained the extract, The extract will be fractionated using solvent with different pollarity. Phytochemical analyses to identification some secondary metabolite used some reagent. Antioxidant activity evaluated by using 2, 2- diphenyl-1-picryl-hydrazyl-hydrate assay The results showed Stem bark Xylocarpus granatum has secondary metabolite compound type Alkaloid, Flavanoid, steroids, polyphenols, and tannin. the antioxidant activity through DPPH radical scavenging showed IC50 value on $31 \mu \mathrm{g}$ / $\mathrm{mL}$ methanol extract, ethyl acetate extract $44.35 \mu \mathrm{g} / \mathrm{mL}, n$-hexane extract $159.82 \mu \mathrm{g} / \mathrm{mL}$ and at fraction of $n$ hexane, ethyl acetate, and water respectively $87.6 \mu \mathrm{g} / \mathrm{mL}, 49.31 \mu \mathrm{g} / \mathrm{mL}, 41.1 \mu \mathrm{g} / \mathrm{mL}$ and ascorbic acid used as a standard of $8.13 \mu \mathrm{g} / \mathrm{mL}$. finally stem bark extract of Xylocarpus granatum has the ability to reduce the radical DPPH so potentially as a natural antioxidant.
\end{abstract}

Keywords: antioxidant, DPPH, Phytochemical, Stem Bark, Xylocarpus granatum.

\section{Introduction}

Free radicals are a chemical compound containing one or more highly unpaired electrons that can cell damage. degenerative diseases such as cancer, diabetes mellitus, atherosclerosis are the result of free radical complications. Free radicals can be reduced with antioxidant compounds[1]. Antioxidants are compounds that give one or more electrons to oxidant compounds so that the oxidant compounds become stable. Antioxidants have the ability to eliminate free radical compounds in the body so as not to induce a disease[2]. Antioxidants are also compounds that can inhibit oxidation reactions, by binding to free radicals and highly reactive molecules that will inhibit the occurrence of cell damage[3].

Xylocarpus granatum is one of the most common mangrove species found in northern buton. Traditionally decoction of the stem bark of this plant is widely used as a herbal drink they believed that drink can increase endurance and prevent from various diseases. The research for antioxidant activity has been performed on its fruit and has antioxidant activity through DPPH radical scavenging[4]. Based on the literature search, there is no research showing the antioxidant activity of the stem bark of this plant, so this study aims to explore the antioxidant activity of Xylocarpus granatum stem bark through DPPH radical scavenging. 


\section{Materials and Methods}

\subsection{Materials}

Stem bark Xylocarpus granatum is obtained from Ereke, northern buton , Indonesia and is authenticated in the Laboratory of Pharmaceutical Biology, Faculty of Pharmacy, Universitas Gadjah Mada (UGM), 2,2diphenyl-1-picrylhydrazyl(DPPH), and other reagents and solvents were purchased from E. Merck (Darmstat, Germany).

\subsection{Methods}

\section{Phytochemical screening}

Test for alkaloids: $0.1 \mathrm{~g}$ of extract added $10 \%$ ammonia solution, then extracted with chloroform and added concentrated $\mathrm{H}_{2} \mathrm{SO}_{4}$. The solution is shaken until phase separation is formed. Acid phase is taken then tested with meyer and dragendorff reagents. The presence of white precipitate with meyer reagent and brown to black sediment to forage with reagent dragendorff showed the existence of alkaloids. Test for polyphenols: Two milliliter of $2 \%$ solution of $\mathrm{FeCl}_{3}$ mixed with crude extract. Black or blue-green color indicated the presence of tannins and phenols. Test for flavonoids: pieces of magnesium ribbon and $\mathrm{HCl}$ concentrated were mixed with crude plant extract after few minutes pink colored scarlet appeared that indicated the presence of flavonoids. Test for steroids: Two milliliter of chloroform and concentrated $\mathrm{H}_{2} \mathrm{SO}_{4}$ were mixed with the entire plant crude extract. In the lower chloroform layer produced red color that indicated the presence of steroids. Test for tannin: Two methods were used to test for tannins. First, about $1 \mathrm{ml}$ of the ethanol extract was added in $2 \mathrm{ml}$ of water in a test tube. 2 to 3 drops of diluted ferric chloride solution was added an observed for green to blue-green (cathechic tannins) or a blue-black (gallic tannins) coloration. Second, $2 \mathrm{ml}$ of the aqueous extract was added to $2 \mathrm{ml}$ of water, a 1 to 2 drops of diluted ferric chloride solution was added. A dark green or blue green coloration indicates the presence of tannins[5]

\section{Determination of DPPH free radical scavenging activity:}

The scavenging activity. In this assay, a $50 \mu \mathrm{L}$ test solutions (extract or fraction solutions with different levels) was added with $1.0 \mathrm{~mL}$ of $0.4 \mathrm{mM}$ methanolic-DPPH and added with methanol in volumetric flask 5.0 $\mathrm{mL}$. The mixture was shaken vigorously using vortex for $1 \mathrm{~min}$ and is allowed to stand for $20 \mathrm{~min}$ at $25 \mathrm{oC}$ in dark room. The absorbance of solution was measured using spectrophotometer at $517 \mathrm{~nm}$ using methanol as blank [1]. The radical scavenging activity was calculated as:

$$
\text { radical scavenging activity }(\%)=\frac{A_{0}-A_{1}}{A_{0}} \times 100 \%
$$

Where $\mathrm{A}_{\mathrm{o}}=$ Absorbance control, $\mathrm{A}_{1}=$ absorbance extract

\section{Result and Discusion}

Phytochemical screening was performed to determine the secondary metabolite in stem bark extract of Xylocarpus granatum. The secondary metabolites of flavonoid and polyphenols are the metabolites that act as free radical scavenging [6] . The results of phytochemical screening can be seen in Table 1.

TABLE I: Phytochemical Screening Stem Bark Extrack of Xylocarpus Granatum

\begin{tabular}{|c|c|c|c|c|c|c|}
\hline Mebolite & 1 & 2 & 3 & 4 & 5 & 6 \\
\hline Alkaloids & + & - & - & - & & + \\
\hline Flavonoids & + & + & - & - & + & + \\
\hline Polyphenols & + & + & - & + & + & + \\
\hline Tannin & + & + & - & - & - & - \\
\hline Steroids & - & - & + & - & - & - \\
\hline
\end{tabular}

$1=$ methanol extract, $2=$ ethyl acetate extract, $3=n$-hexane extract, $4=$ n-hexane fraction, $5=$ ethyl acetate fraction, $6=$ water fraction 
The antioxidan activity was determinated by the ability of extract to reduce DPPH radical. reduce ability is seen based on absorbance DPPH radical before added and after added extract. then wec converted into perc

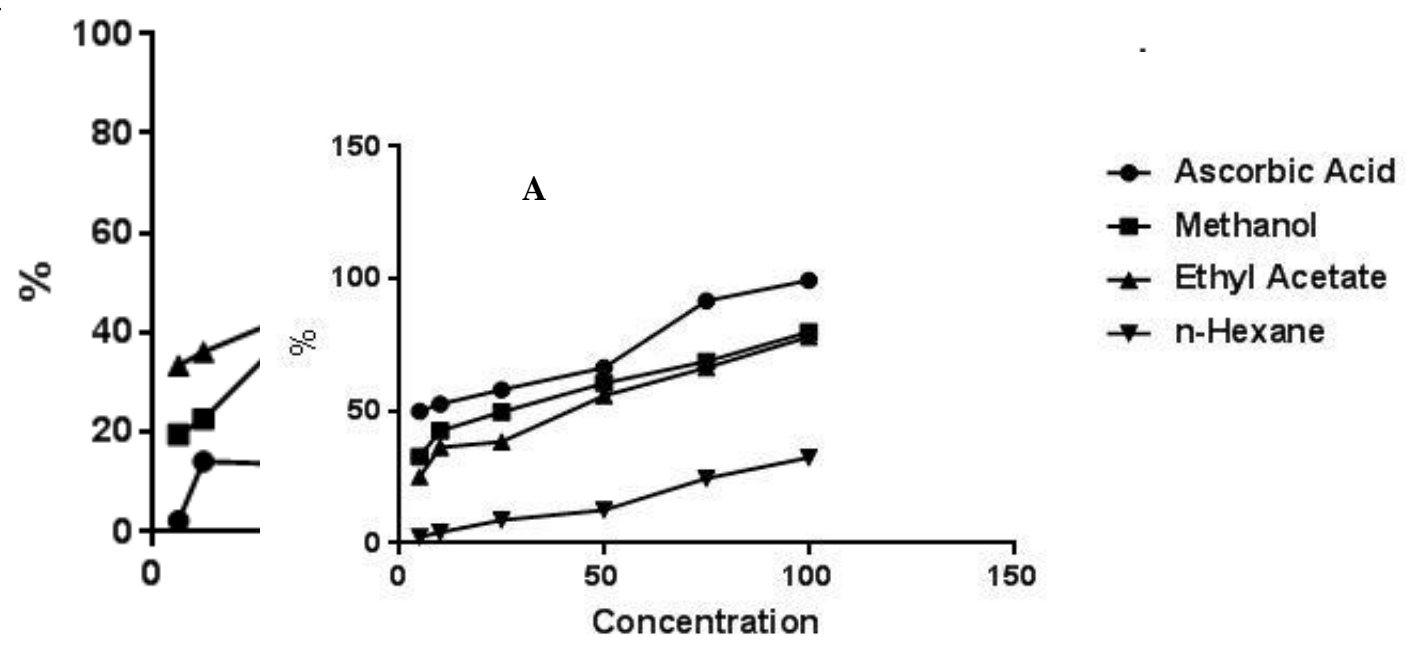

B

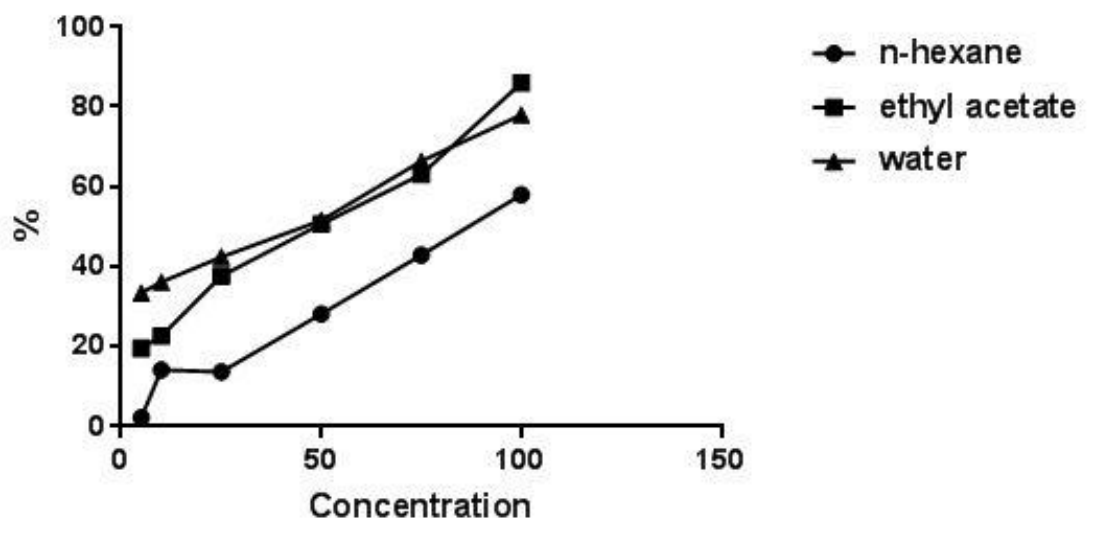

Fig. 1: Radical scavengin of DPPHwith (A) stem bark ex tract of Xylocarpus granatum dan (B) methanol fraction

Based on the picture seen percent inhibition is directly proportional to the concentration.. Methanol extract is very potential to be developed as a natural antioxidant compared to the overall extract of this can be seen based on the calculation of IC50 is written in table 2. IC50 value shows the concentration of extracts that have the scavenging of $50 \%$ DPPH radical[7].

TABLE II: DPPH Radical Scavening Stem Bark Extrack of Xylocarpus Granatum

\begin{tabular}{|l|l|}
\hline Extract/ Fraction & $\mathrm{IC}_{50}(\mu \mathrm{g} / \mathrm{mL})$ \\
\hline Methanol & 31 \\
\hline Ethyl Acetate & 44.35 \\
\hline n-hexane & 159.82 \\
\hline n-hexane Fraction & 87.6 \\
\hline Ethyl acetate Fraction & 49.31 \\
\hline Water Fraction & 41.1 \\
\hline Ascorbic acid & 8.13 \\
\hline
\end{tabular}

The potency of radical inhibition of DPPH by methanol extract is due to the secondary metabolite content possessed by the extract. Phenolic and flavonoids contribute significantly to DPPH free radical absorption. Phenolics and flavonoids contribute one electron to the DPPH radical so as to stabilize DPPH[8]. 


\section{Conclusion}

Stem bark extract of Xylocarpus granatum capable of reducing DPPH radical so it is potentially developed as a natural antioxidant.

\section{Acknowledgements}

Author thanks for the Indonesia Endowment Fund for Education, Ministry of the Finance Republic of Indonesia (LPDP) for the give me fund to presentased this paper

\section{References}

[1] Antasionas I, Riyanto S, Rohman A. Antioxidant Activities and Phenolics Contents of Avocado (Persea americana Mill.) Peel in vitro. Res J Med Plants. 2017 Mar 15;11(2):55-61. https://doi.org/10.3923/rjmp.2017.55.61

[2] Kikuzaki H, Hisamoto M, Hirose K, Akiyama K, Taniguchi H. Antioxidant Properties of Ferulic Acid and Its Related Compounds. J Agric Food Chem. 2002 Mar;50(7):2161-8H. Poor, An Introduction to Signal Detection and Estimation. New York: Springer-Verlag, 1985, ch. 4.

[3] Gülçin İ, Mshvildadze V, Gepdiremen A, Elias R. Antioxidant Activity of Saponins Isolated from Ivy: $\alpha$-Hederin, Hederasaponin-C, Hederacolchiside-E and Hederacolchiside-F. Planta Med. 2004 Jun;70(6):561-3. https://doi.org/10.1055/s-2004-827158

[4] Zamani N, Gazali M. The Study of Tyrosinase and Antioxidant Activity of Xylocarpus Granatum Koenig Seed Kernel Extract toward Evidence Based Indigenous Knowledge from Togean Archipelago, Indonesia. J Mar Sci Res Dev. 2015.

[5] Zohra SF, Meriem B, Samira S, Muneer MA. Phytochemical screening and identification of some compounds from mallow. J Nat Prod Plant Resour. 2012;2(4):512-6

[6] Procházková D, Boušová I, Wilhelmová N. Antioxidant and prooxidant properties of flavonoids. Fitoterapia. 2011 Jun;82(4):513-23.

https://doi.org/10.1016/j.fitote.2011.01.018

[7] Attanayake AP, Jayatilaka K. Evaluation of antioxidant properties of 20 medicinal plant extracts traditionally used in Ayurvedic medicine in Sri Lanka. 2016;

[8] Li X, Wu X, Huang L. Correlation between Antioxidant Activities and Phenolic Contents of Radix Angelicae Sinensis (Danggui). Molecules. 2009 Dec 21;14(12):5349-61.

https://doi.org/10.3390/molecules14125349 